\title{
Update on "Fat Injection for Cases of Severe Burn Outcomes: A New Perspective of Scar Remodeling and Reduction"
}

\author{
Marco Klinger $^{1} \cdot$ Silvia Giannasi $^{1} \cdot$ Valeria Bandi $^{1} \cdot$ Alessandra Veronesi $^{1}$ • \\ Luca Maione $^{1} \cdot$ Andrea Lisa $^{1} \cdot$ Andrea Battistini $^{1} \cdot$ Fabio Caviggioli $^{2}$. \\ Francesco Klinger ${ }^{2} \cdot$ Valeriano Vinci $^{3}$
}

Published online: 5 August 2020

(C) Springer Science+Business Media, LLC, part of Springer Nature and International Society of Aesthetic Plastic Surgery 2020

The study that our group published on May 2008 entitled "Fat Injection for Cases of Severe Burn Outcomes: A New Perspective of Scar Remodeling and Reduction" was a breakthrough in the plastic surgery scientific literature since it opened the way to a new concept of scar treatment (simple, hypertrophic and keloids) [1].

In that paper, we evaluated three adult patients with hemifacial hypertrophic scars and keloids resulting from severe burns. These patients' scars were treated by autologous fat grafting (AFG) injection. We were able to show that the clinical appearance and subjective patient feelings after a 6-month follow-up period were tremendously improved in terms of mimic features, skin texture and thickness. The observed clinical findings were confirmed at histological examination which showed patterns of new collagen deposition, local hypervascularity and dermal hyperplasia in the context of the new tissue, having a relevant correspondence with original cutaneous tissue.

Before this innovative research was published, scars were usually treated with surgical scar revision and/or local flaps (Z-plasty or V-Y closure). We were the first to

Marco Klinger

marco.klinger@humanitas.it

1 Plastic Surgery Unit, Department of Medical Biotechnology and Translational Medicine BIOMETRA, Humanitas Clinical and Research Hospital, Reconstructive and Aesthetic Plastic Surgery School, University of Milan, Via Manzoni 56, 20090 Rozzano, MI, Italy

2 Plastic Surgery Unit, MultiMedica Holding S.p.A., Reconstructive and Aesthetic Plastic Surgery School, University of Milan, Sesto San Giovanni, Milan, Italy

3 Humanitas Clinical and Research Center - IRCCS, Via Manzoni 56, 20089 Rozzano, MI, Italy demonstrate the efficacy of a totally different and innovative surgical technique.

After the first experience in 2007 [2] that demonstrated the efficacy of lipofilling on radiodistrophic tissues, we were the first group in the world to show that this easy and safe surgical procedure could become the gold standard in scar treatment. Our group was also the first to highlight the importance of AFG in combination with needles. Over the years, we have gained a lot experience on burn patients and we have found that scar tissue is characterized by overflowing fibrous tissue that achieves a significant resistance to the sliding of classical blunt cannulas. For this reason, we decided to employ 18-gauge angiographic needles [3], which are able to overcome the strength of the fibrous tissue resistance, thus making it possible to lay a constant amount of fat (in a retrograde fashion) inside the whole thickness of the scar and, if needed, at the dermal-hypodermal junction by multiple radiating passages that distribute fat in all directions. They are very useful also because of their ability to reduce the tensile strength of the scar and the tension on the surrounding tissues. We have also discovered that needles stimulate new collagen deposition and remodeling of fibrous tissues, in a fashion similar to the "needling" procedure used in aesthetic medicine [4]. This procedure has been widely used by many other surgeons later, such as Rigotti, who gave the name of this procedure as "Rigottomies" [5].

In 2013, we published another paper entitled "Autologous Fat Graft in Scar Treatment" [6] in which we discovered that the effects of the lipofilling can be seen starting from 3 weeks after the procedure, in terms of better scar color, pliability, thickness, relief, itching, pain, scar vascularization and pigmentation. Indeed, autologous fat grafting makes the skin softer, more flexible and 
extensible; besides, the color seems similar to the surrounding unharmed skin. In this article, we analyzed different types of scars, from burn injuries, malformation correction sequelae, road traumas, domestic accidents and different surgery procedures (more specifically from breast oncologic or orthopedic surgery). Based on this study, we were able to show that lipofilling and needles can be used in every scar, whatever its origin.

In few years, thanks to excellent studies conducted by other groups, the mechanism by which lipofilling exerts its effects has been reported: mesenchymal cells contained in adipose tissue have a primary role in terms of regenerative properties. The biological/biochemical effects are still not completely understood, but the mesenchymal multipotent stem cells within fat are responsible for remodeling of the scars through engraftment and differentiation. This leads to molecular changes in the microenvironment of the scars (local action of growth factors, enzymes, cytokines, angiogenic factors and cellular components stored in the lipoaspirate) leading to neoangiogenesis inside the fibrotic tissue. Consequently, autologous fat grafting can improve the quality of the scar tissue, regenerate the dermis and subcutaneous tissue, improve the quality of the dermal and dermo-hypodermic areas and, if needed, give volume to specific body areas.

Throughout the time, our group has adopted this technique not only in regenerative surgery, but also for aesthetic purposes. Many papers have been published, showing the effect of lipofilling in treating not only scars, but also chronic wounds, neuropathies and volume deficits [7-12]. Afterward, we were able to show the ability of AFG to treat the post-mastectomy pain syndrome [13, 14] and other neuropathies such as Arnold's neuralgia and migraine headaches [15-17]. In another paper, we were able to define the lipofilling and needles as a safe procedure in terms of complications rate [18].

In the last period, we have focused our attention on the use of AFG and needles for the treatment of stenotic and tuberous breasts. In our practice, we have observed that patients suffering from tuberous breasts manifested skin, parenchyma, fascia and vascular alterations. The results of our analysis showed significant differences in quantity and disposition of collagen fibers in patients with tuberous breasts, compared to normal breasts. After numerous histological examinations, we were able to define that collagen fibers appear altered in disposition and quantity, occasionally assembled in bundles determining the typical glandular toughness, ligament and fascial thickening and general fibrosis. For this reason, we can consider the affected pole (lower) of the stenotic breast as a scar/fibrotic tissue and, as such, can be treated with a combination of AFG and needles. Less severe cases can be even treated with needles only. The data are still preliminary, but we can say that lipofilling and needles are an important step for the correction of whatever form of stenotic breast [19-21].

\section{References}

1. Klinger M, Marazzi M, Vigo D, Torre M (2008) Fat injection for cases of severe burn outcomes: a new perspective of scar remodeling and reduction. Aesthet Plast Surg 32(3):465-469

2. Rigotti G, Marchi A, Galie' M, Baroni G, Benati D, Krampera M, Pasini A, Sbarbati A, (2007) Clinical treatment of radiotherapy tissue damage by lipoaspirate transplant: a healing process mediated by adipose-derived adult stem cells. Plast Reconstr Surg 119:1409-1422

3. Caviggioli F, Forcellini D, Vinci V, Cornegliani G, Klinger F, Klinger M (2012) Employment of needles: a different technique for fat placement. Plast Reconstr Surg 130:373e-374e

4. Aust MC, Fernandes D, Kolokythas P, Kaplan HM, Vogt PM (2008) Percutaneous collagen induction therapy: an alternative treatment for scars, wrinkles, and skin laxity. Plast Reconstr Surg 121(4):1421-1429

5. Khouri RK, Rigotti G, Cardoso E, Khouri RK Jr, Biggs TM (2014) Megavolume autologous fat transfer: part II. Practice and techniques. Plast Reconstr Surg 133(6):1369-1377

6. Klinger M, Caviggioli F, Klinger FM, Giannasi S, Bandi V, Banzatti B, Forcellini D, Maione L, Catania B, Vinci V (2013) Autologous fat graft in scar treatment. J Craniofac Surg 24(5):1610-1615

7. Klinger M, Caviggioli F, Klinger F, Pagliari AV, Villani F, Bandi V (2009) Scar remodeling following burn injuries. In: Coleman SR, Mazzola RF (eds) Fat injection: from filling to regeneration. Quality Medical Publishing, St Louis

8. Klinger M, Caviggioli F, Forcellini D, Villani F (2009) Scars: review of emerging and currently available therapies. Plast Reconstr Surg 124(1):330

9. Caviggioli F, Maione L, Vinci V, Klinger M (2010) The most current algorithms for the treatment and prevention of hypertrophic scars and keloids. Plast Reconstr Surg 126(3):1130-1131

10. Klinger M, Lisa A, Klinger F, Giannasi S, Veronesi A, Banzatti B, Bandi V, Catania B, Forcellini D, Maione L, Vinci V, Caviggioli F (2015) Regenerative approach to scars, ulcers and related problems with fat grafting. Clin Plast Surg 42(3):345-352

11. Klinger M, Klinger F, Caviggioli F, Maione L, Catania B, Veronesi A, Giannasi S, Bandi V, Giaccone M, Siliprandi M, Barbera F, Battistini A, Lisa A, Vinci V (2020) Fat Grafting for Treatment of Facial Scars. Clin Plast Surg 47(1):131-138

12. Caviggioli F, Klinger F, Villani F et al (2008) Correction of cicatricial ectropion by autologous fat graft. Aesthet Plast Surg 32(3):555-557

13. Caviggioli F, Maione L, Forcellini D, Klinger F, Klinger M (2011) Autologous fat graft in postmastectomy pain syndrome. Plast Reconstr Surg 128:349-352

14. Caviggioli F, Vinci V, Maione L, Lisa A, Klinger M (2013) Autologous fat grafting in secondary breast reconstruction. Ann Plast Surg 70(1):119

15. Klinger M, Gaetani P, Villani F, Klinger F, Rodriguez Y, Baena R, Levi D (2009) Anatomical variations of the occipital nerves: implications for the treatment of chronic headaches. Plast Reconstr Surg 124(5):1727-1728

16. Caviggioli F, Giannasi S, Vinci V, Cornegliani G, Levi D, Gaetani P (2011) Five-year outcome of surgical treatment of migraine headaches. Plast Reconstr Surg 128(5):564e-565e

17. Gaetani P, Klinger M, Levi D, Bussone G, Giannasi S, Caviggioli F, Marazzi M, Broggi G (2013) Treatment of chronic headache of 
cervical origin with lipostructure: an observational study. Headache 53:507-513

18. Maione L, Vinci V, Klinger M, Klinger FM, Caviggioli F (2015) Autologous fat graft by needle: analysis of complications after 1000 patients. Ann Plast Surg 74(3):277-280

19. Klinger M, Caviggioli F, Klinger F, Villani F, Arra E, Di Tommaso L (2011) Tuberous breast: orphological study and overview of a borderline entity. Can J Plast Surg 19(2):42-44

20. Klinger M, Caviggioli F, Giannasi S, Bandi V, Banzatti B, Veronesi A, Barbera F, Maione L, Catania B, Vinci V, Lisa A, Cornegliani G, Giaccone M, Siliprandi M, Klinger F (2016) The prevalence of tuberous/constricted breast deformity in population and in breast augmentation and reduction mammaplasty patients. Aesthet Plast Surg 40(4):492-496

21. Klinger M, Klinger F, Maione L, Vinci V, Lisa A, Barbera F, Caviggioli F (2019) Stenotic Breast malformation and its reconstructive surgical correction: a new concept from minor deformity to tuberous breast-author response. Aesthet Plast Surg 43(4):1117

Publisher's Note Springer Nature remains neutral with regard to jurisdictional claims in published maps and institutional affiliations. 